\title{
16
}

\section{CHINA AND THE KOREAS An Australian perspective}

\author{
Rowan Callick
}

Politicians of every stripe try to uphold one common code: do not answer hypothetical questions. Journalists are a different breed. We thrive on the what-ifs that life throws up, so I guess I have to be prepared to accept the challenge. What is going to happen in the future on the Korean Peninsula, and in Korea's relations with China? And how is that likely to affect Australia?

On 28 September 2011, the then Prime Minister Julia Gillard delivered what was to me an impressive speech about a proposed white paper concerning Australia in the Asian century-impressive in its scope, ambition and realism. She said that instead of suffering as in past decades and centuries from the tyranny of distance, Australia is now benefiting from its proximity to the new centre of global economic gravity. She went on to say:

While so much is new, many old tensions remain - and the classical world of inter-state rivalries never really went away. With no better example than the Korean Peninsula-where a republic whose friendship Australia greatly values prospers with a free future and [yet] remains threatened by its neighbour: a rogue state which is a threat to its near neighbours, to the region as wholeand to its own captive people above all. ${ }^{1}$

1 Asia Society, 'Australia PM Julia Gillard on Australia’s role in Asia', 28 September 2011, asiasociety.org/australia-pm-julia-gillard-australias-role-asia. 
Thus does the Republic of Korea (ROK) continue to be defined by a negative - by its relationship to its evil twin North Korea.

When the Lowy Institute, Australia's only internationally focused think tank, conducted its annual opinion poll in 2017, its section dedicated to the Korean Peninsula was, inevitably, about war. Previous Lowy Polls have indicated that North Korean heightened brinkmanship, the sinking of the South Korean corvette Cheonan in 2010 and the shelling of the South Korean island of Yeonpyeong made a considerable impression on Australian public opinion.

In this context, Australians were asked by the Lowy Institute in 2017: 'If North Korea invaded South Korea', could the involvement of Australian military forces be justified? By a small margin Australians were more likely not to support Australian military forces being committed to a conflict on the Korean Peninsula in this case ( 48 per cent), whereas 45 per cent of respondents were in favour of sending military forces. In the event that 'China initiated a military conflict with one of its neighbours over disputed island or territories', the Lowy Institute Poll found that 58 per cent of respondents were likely to oppose Australia's use of military force. ${ }^{2}$ The poll also indicated that approximately 65 per cent of the Australian public believe that North Korea's nuclear program is the second highest threat to 'Australia's vital interests'. ${ }^{3}$

Asked by the Lowy Institute about their feelings towards various countries-on a scale with 100 degrees meaning very warm, 50 degrees lukewarm and zero degrees frozen-South Korea was awarded 60 degrees, Japan 71 degrees, USA 69 degrees, United Kingdom 81 degrees and New Zealand took out the top spot with 85 degrees. Towards the bottom came North Korea with a score of 30 degrees, Russia with 50 degrees and Indonesia scoring only 55 degrees. ${ }^{4}$

South Korea is Australia's fourth-largest trading partner and two-way trade between 2016 and 2017 amounted to $\$ 38.7$ billion, making up 5.3 per cent of all Australia's international trade. ${ }^{5}$ The ROK is the tenth largest importer of natural gas, and Australia is among the world's biggest

2 A. Oliver, '2017 Lowy Institute Poll', 21 June 2017, www.lowyinstitute.org/publications/2017lowy-institute-poll.

3 Ibid.

4 Ibid.

5 Department of Foreign Affairs and Trade, 'Republic of Korea country brief', dfat.gov.au/geo/ republic-of-korea/pages/republic-of-korea-south-korea-country-brief.aspx. 
suppliers of natural gas. ${ }^{6}$ The Abbott government (2013-15) presided over the signing of the Korea-Australia Free Trade Agreement (KAFTA), which came into force in December 2014. ${ }^{7}$ There are a considerable number of Koreans in Australia: in the 2011 census there were 74,538 South Korean-born residents and 88,973 with Korean ancestry. ${ }^{8}$

Alison Carroll, the founding director of Melbourne-based Asialink Arts, has said: 'An energy is coming out of Korea that we in Australia just don't know about. When we send artists there-35 in recent years-they have a great time and come back enthusing. One video artist we sent never came back at all, and now represents Korea internationally.'

My newspaper, the Australian, ran a story in 2011 by our Tokyo-based correspondent for Japan and Korea, Rick Wallace, about the wave of Korean cultural exports, especially pop culture, which earned the country $\$ 3.8$ billion that year. Cui Jian, China's most famous rock star, the Mick Jagger of the People's Republic, is famously of Korean descent. His father was a jazz musician. Cui told me in an interview that he cannot speak Korean, but at family occasions 'we party Korean style'. Yet the Korean language is taught in fewer than 50 schools across Australia, and not a single student studying Korean in his or her final year of high school comes from a non-ethnic Korean background.

It would appear that we are aware of the Korean War-that it is not, as has been said, 'a forgotten war fought in a forgotten country'. Indeed, we appear to be ready to help fight in another Korean war should it be triggered. And that is a pretty big commitment, just about the biggest that people can make. But for the rest, well, we just do not know that much about Korea, really.

China has, effectively, grabbed most of the space available for the engagement with Asia that Julia Gillard began in 2011. That year was the Australia-Korea Year of Friendship, employing the slogan 'celebrating mateship'. I would like to say something more positive about it, but I fear that it passed almost unnoticed by Australians. In his prime ministerial days, Kevin Rudd was an exception. He was the first foreign

\footnotetext{
6 'The World Factbook', Central Intelligence Agency, www.cia.gov/library/publications/resources/ the-world-factbook/.

7 Department of Foreign Affairs and Trade, 'Republic of Korea country brief'.

8 Department of Home Affairs, 'Community Information Summary The Republic of (South) Korea-Born’, www.homeaffairs.gov.au/mca/files/2016-cis-south-korea.pdf.
} 
leader to publicly express condemnation of the sinking of the Cheonan. 'The international community', he said, 'cannot let this act pass without an appropriate response.' But, of course, pass it did. And if the 'international community', whatever that might be, did indeed make a response, I would suggest that it was probably not appropriate.

Rudd, though, developed a close relationship with President Lee Myungbak, forging links between what Rudd saw as two middle powers in the same region. Both countries joined the G20, Canberra's global summitry vehicle of choice. During a visit to Australia, Lee signed a security framework, only South Korea's second after its US alliance. The security relationship continues to grow as both countries deploy troops to the same theatres. Five Australian defence experts were among the team that confirmed it was a North Korean torpedo that sank the Cheonan, although they were not available to discuss their findings with the media here. For a while it looked as if our free-trade agreement negotiations with Seoul, although they started years after those with Beijing and Tokyo, would be completed first, but it was not until after the Abbott government came to power (in 2013) that KAFTA was signed.

John Walker, the chairman of the Macquarie Group in South Korea and probably Australia's leading business champion there, described the new Korea in 2011 as 'a powerhouse of global expansion'. Its construction companies, resource corporations and others are winning contracts and acquiring businesses in all markets, particularly emerging markets. However, he went on, 'there is a minimal Aussie corporate presence in Korea', and asked whether Korea was being 'confined by Australians to the status of a geopolitical relationship'. After Prime Minister Gillard's April 2011 visit to Korea, he said that she had covered a lot of ground, made a well-received visit to the scene of the battle at Kapyong, and did her best to link, rather than separate, geopolitical stability and commercial opportunities.

South Korea is setting itself up well, becoming the world's most wired country, with a good education system and an economy that was re-created following the Asian financial crisis of the late 1990s. For once it finds itself in a fortunate location, next to both China, the world's fastest growing economy, and Japan with its cashed-up innovative corporations more eager to go abroad than stay home. This is just as well, because South Korea has only modest physical resources. It will continue to buy substantial minerals and sources of energy, especially gas, from Australia. 
Mutual investment should accelerate-provided Seoul does not tip the scales too much in favour of its local favourites, as was perceived to have happened over the ANZ Bank's failed 2010 bid for the Korea Exchange Bank.

But what about events above the 38th parallel?

North Korea is a place that raises a big question mark over Julia Gillard's remark in her 2011 speech that Australians are 'no longer subjects of the "tyranny of distance"': 'Asia has turned this on its head, giving us what the Economist has neatly termed "the advantage of adjacency". For the first time, we are closer to the fastest growing and most economically dynamic region of the world than our competitors.' Just take the Democratic People's Republic of Korea (DPRK) for example. Nowhere could be better positioned. A 1,400-kilometre border with the world's fastestgrowing economy. A 240-kilometre border with the Republic of Korea, the thrusting new industrialised middle power. A 20-kilometre border with Russia, one of the world's great sources of resources and energy. And a mere paddle across from Japan, the world's third biggest economy.

Yet North Korea is an economic and human rights wreck. It is amazing to think that more than 50 years ago it was an oasis of comparative wealth, while South Koreans were strongly advised by the United Nations to look to Kenya as a model for development. How times have changed. North Korea's absolute failure to benefit from geographic advantage is unlikely to be transformed any time soon. We have seen too many false reformist dawns to believe that after his next magical mystery train tour through some of China's most successfully modernising provinces, Kim Jong-un will start to adopt an open-door strategy.

Russian scholar and Korean studies specialist Andrei Lankov worked at The Australian National University for seven years before shifting to Kookmin University in Seoul in 2004. In his book, The Real North Korea: Life and Politics in the Failed Stalinist Utopia, Lankov tried his hand at prediction, something he is not shy of:

One cannot help but get a very dire picture of an insane dictatorship whose leaders enjoy a seemingly meaningless sabrerattling while their subjects live under the constant threat of another murderous famine ... 'Capitalism from below' has brought social stratification, but the new middle class (and, of course, the rich and powerful) can now afford items which were 
unheard of in Kim Il Sung's time. However, the North Korean system has one major shortcoming-it cannot be reformed. The major obstacle is the existence of the rich South, and this is what makes any attempts at a managed transformation risky or even suicidal for the current elite.

But Lankov is cynical about the effect of any improvements on the lot of North Korean citizens.

At the same time, less daily economic pressure might mean more time to think, talk and socialize for the North Korean citizensand this is not good news for the regime ... people seldom start revolutions when they are desperate.

Thus the most rational survival strategy for the DPRK government is to change nothing. They will probably succeed at this task for a while. If Kim Jong-un ... wants to stay in power he has to follow three simple rules. First, to avoid Chinese-style reforms and liberalization; second, to continue the zero-tolerance policy against dissent (anybody who dares to criticize the government should be dead or in a prison camp in no time); third, to inhibit and, whenever possible, roll back the spontaneous growth of capitalist institutions ... The greater the gap between the North and its neighbours - above all South Korea-will become, the greater the potential for a future explosion is likely to be. ${ }^{10}$

Lankov is seriously concerned about the North Korean endgame going violent:

Another possible endgame trigger is the outbreak of serious factional infighting within the top leadership. But it seems that North Korean leaders have internalized the dictum of Benjamin Franklin, who famously said, 'Gentlemen, if we are not hanged together we will surely be hanged separately.'

The third possible scenario of the endgame is a spontaneous outbreak of popular discontent, a local riot quickly developing into a nationwide revolutionary movement-somewhat similar to what we have seen in 2011 in the Arab world. The fourth scenario

9 A. Lankov, The Real North Korea: Life and Politics in the Failed Stalinist Utopia, Oxford University Press, New York, 2013, p. 188.

10 Ibid., pp. 189, 190. 
is contagion from some unrest in China-the only country where an outbreak of civilian disobedience or riot might produce some impact on North Korea.

There are few reasons to expect a North Korean revolution to be 'velvet' ... It is located in the middle of a highly developed region, while its small size and long coastline make projection of force much easier. Last but not least, it has considerable nuclear stockpiles and a large WMD arsenal which no major international player would like to see unattended. ${ }^{11}$

Lankov concludes:

The widespread hope that the emergence of reformist groups will finally bring about a non-nuclear, non-threatening and developing North Korea seems to be wishful thinking. There are only two possible long-term outcomes: either a unification of Korea under the auspices of Seoul or a relatively stable China-controlled satellite regime-meaning that the division of Korea will become permanent. $^{12}$

What might this mean for Australia? Canberra has attempted, from time to time, to play a minor role in the Great Game on the peninsula. Its lack of participation in the six-party talks has limited its options. The DPRK had an embassy in Canberra from 1974 to 1975, and again from 2002 to 2008, when it closed for financial reasons. Inevitably, there were a few bizarre incidents in this period, capped by the use in 2003 of the Pong Su, a North Korean freighter, to smuggle about 150 kilograms of heroin into Victoria. Four men were arrested, and one drowned bringing the heroin ashore. An official of the ruling Korean Workers' Party was on board. The ship tried to escape into international waters but was boarded by Special Operations forces via helicopter, and the vessel was later scuttled-after its radio had been removed and donated to the Kurrajong Radio Museum. All quite exciting, but ultimately inconclusive.

In 2008 Australia shifted its handling of North Korean matters from our embassy in Beijing to the one in Seoul. In 2011 AusAID budgeted A \$5 million for humanitarian assistance, and Australia has stopped providing humanitarian aid to the DPRK through UN agencies as of 
late 2017. ${ }^{13}$ More recently, the then Prime Minister Malcom Turnbull described North Korea as 'one of the world's most "cunning, sophisticated criminals"'. ${ }^{14}$

China, Japan and the United States comprise Australia's first, second and third export markets, respectively. Any conflict in that region risks rocking Australia's continuing Asia-driven boom. But the world has run out of solutions. Kevin Rudd, when prime minister, lamented that North Korea 'does not respond to normal international diplomatic discourse'. Turnbull has ratcheted up the rhetoric against the DPRK to such an extent that he stated, 'whether it is arms, whether it is cyber-crime, whether it is drugs they are constantly raising money to finance their nuclear program. ${ }^{15}$

Hong Lei, an acquaintance of mine who was the Chinese Foreign Ministry spokesman, said in a hand-wringing way after North Korea's shelling of the island of Yeonpyeong, 'We hope that the relevant parties will contribute their share to peace and stability on the Korean Peninsula'. In 2010 US President Barack Obama's Special Representative for North Korea Policy, Stephen Bosworth, urged the international community to join the United States in calling for Pyongyang to 'cease its provocative and irresponsible actions against its neighbour'. Victor Cha, a former US national security official, said that North Korea is 'the land of lousy options' for all involved. The United States, the country that Pyongyang most wishes to provoke into dealing with it directly, and China, North Korea's sole surviving ally and chief supplier of oil and other strategic resources, both appear, in relation to the DPRK, to be running on empty-except for hope.

Rudd said in 2010, 'It's very important for China to take an increasingly assertive role with North Korea'. Rudd was not on his own there. Beijing wished to extend its influence in the region, and especially in South Korea, which was for a decade becoming increasingly enmeshed with China, where among the expatriates there are more South Koreans than any other nationality.

13 Department of Foreign Affairs and Trade, 'Department of Foreign Affairs and Trade Annual: Report 2011-2012', webarchive.nla.gov.au/wayback/20190210114628/https:/dfat.gov.au/aboutus/publications/corporate/annual-reports/annual-report-2011-2012/pdf/DFAT_AR_2011-12.pdf. 14 L. Murdoch, 'Malcolm Turnbull calls North Korea “criminals”, urges Hong Kong to help', Sydney Morning Herald, 12 November 2017, www.smh.com.au/politics/federal/malcolm-turnbullcalls-north-korea-criminals-urges-hong-kong-to-help-20171112-gzjp85.html.

15 Ibid. 
When I visited North Korea a few years ago, it was hard to see any light at the end of the tunnel, despite the occasional store set up in tent-like kiosks, selling bric-à-brac from China. Despite the constant reminders of the brutal war of 1950-53, and despite the continuing militarisation of the country, they seemed to be starting to feel invulnerable. An official guide said to me as we drove, almost free of traffic because of the lack of petrol, past one of the many tank traps-massive concrete pillars alongside the ill-kept freeway between the capital and the border: 'There's no need for these tank traps any more, because now we have the nuclear bomb. We're safe and we're at peace.'

It is the peace of the grave, however. The skyline of Pyongyang is dominated by the pyramid-shaped, 105-storey Ryugyong Hotel building. Its brooding presence is like that of a Mayan temple mouldering in a jungle clearing, reminding travellers of lost empires and the transience of power. At night, there was scarcely a light to be seen in this city of 3 million. Electricity was available only sporadically. As a result, no one bothered even to try to acquire fridges, but they would hang around outside their blocks of flats, some of which reached 30 storeys or more, in the hope of being able to use the lift to get home sometime soon. In the second city, Hamhung, women washed clothes by hand on the rocks alongside a river flowing in front of their apartment blocks. In Pyongyang I saw trolley buses in which everyone, including the driver, was fast asleep, like the world of the Sleeping Beauty, as they waited for power to return so they could go home or get to work. It is all the fault of the Americans, I was told. Once the Americans leave South Korea, their compatriots will celebrate their freedom by inviting the Dear Leader-or the General, as he is more widely called-to rule them too.

When I arrived on an ancient Tupolev propeller plane, they took my mobile phone and kept it in a cabinet at the airport. The guide said it would be good to keep in touch by email; he explained that he was one of the privileged few with such access-but his address was shared by a dozen others, so everyone could read each other's mail. I met groups of young Chinese tourists there who said they were visiting to see how harsh life would have been for their parents in the bad old days before Deng declared, 'To get rich is glorious'. The renminbi is widely accepted as the de facto hard currency of North Korea. 
As I flew out in mid-afternoon, the airport was being closed. Ours was the final flight of the day. As soon as we touched down back in Shenyang in north-eastern China, the mobile phones begin to beep and buzz as if making up for lost time. The massive, modern Shenyang airport was bustling with flights heading in every direction, all through the night.

These two places, which only a few decades ago seemed to speak the same language, are now poles apart in so many ways. Yet the failure of China to categorically step away from its support for the rogue state of North Korea serves to underline China's own failure to step away from its all-seeing, omnipotent Party, which steers what remains essentially a command economy. It is as if the Politburo Standing Committee cannot bear to risk being perceived as betraying the sacrifice of the 28-year-old Mao Anying, Mao Zedong's eldest and most loved son, who died in Korea in 1950 from a napalm bomb dropped by a South African Air Force A-26 bomber.

In general, Australians view China more as opportunity than as threat; everyone knows how important Chinese demand has been for our economy. The 2017 Lowy Institute poll showed that the vast majority of Australians see China as more of an economic partner ( 79 per cent) rather than a military threat (13 per cent). Interestingly, opinion is more evenly split on the question of whether or not China is likely to present a military threat in the next 20 years. ${ }^{16}$ Professor Alan Dupont of Sydney University says that China ultimately wants 'to push the US into the central Pacific as far as possible', and Hugh White of The Australian National University has focused on the strains of no longer having our major economic partner also our main security partner for the first time in Australia's history.

In her 2011 speech Julia Gillard said that 'we are now seeing the most profound rebalancing of global wealth and power in the period since the United States emerged as a major power in the world'. ${ }^{17}$ She gave, as an illustration of that shift, her view that the emerging and developing world could well become a net foreign investor, while developed countries become net foreign borrowers, as early as 2025 . This view has only been reinforced since then.

16 Oliver, '2017 Lowy Institute Poll'.

17 Asia Society, 'Australia PM Julia Gillard on Australia's role in Asia'. 
The fate of the Korean Peninsula within this shift must remain open: one half heading in one direction, engaging in an increasingly effective way with its neighbours, including Australia, if it can be counted as such; the other half remaining in mountain-clad feudal isolation-the whole a kind of fable of human progress, its possibilities and its failures, in one place. Convulsive change will probably come, in Korea as in China. But I am not predicting it will come any time soon, or if so, how.

William Shakespeare would have written, if he were alive today, about this big theme, this big story, with its continuing tragedies of divided families and lost warriors. As Macbeth reaches its conclusion, our heroor rather anti-hero-recalls being told by the witches that he will be safe 'till Birnam Wood shall come' to his castle at Dunsinane, which of course transpires. I was reminded keenly of this when being told by a senior South Korean official of an early tentative negotiating session with DPRK cadres who had come south to Seoul. The leading North Korean remarked as the talks opened that he knew that the southerners had brought most of the cars in the south to Seoul specially to create an impression. The top South Korean negotiator responded that this was true, that their ruse had been rumbled. He added, 'What's more, we dragged all the skyscrapers in the country here too'. 
This text is taken from In from the Cold: Reflections on Australia's Korean War, edited by John Blaxland, Michael Kelly and Liam Brewin Higgins, published 2020 by ANU Press, The Australian National University, Canberra, Australia. doi.org/10.22459/IFTC.2019.16 